\title{
THE
}

$5-10-2008$

\section{Mineralization of ancient carbon in the subsurface of riparian forests}

Noel P. Gurwick

Daniel M. McCorkle

Peter M. Groffman

Arthur J. Gold

University of Rhode Island, agold@uri.edu

D. Q. Kellogg

University of Rhode Island

See next page for additional authors

Follow this and additional works at: https://digitalcommons.uri.edu/nrs_facpubs

Part of the Environmental Sciences Commons

Terms of Use

All rights reserved under copyright.

\section{Citation/Publisher Attribution}

Gurwick, N. P., D. M. McCorkle, P. M. Groffman, A. J. Gold, D. Q. Kellogg, and P. Seitz-Rundlett (2008), Mineralization of ancient carbon in the subsurface of riparian forests, J. Geophys. Res., 113, G02021, doi:10.1029/2007JG000482

Available at: http://dx.doi.org/10.1029/2007JG000482

This Article is brought to you for free and open access by the Natural Resources Science at DigitalCommons@URI. It has been accepted for inclusion in Natural Resources Science Faculty Publications by an authorized administrator of DigitalCommons@URI. For more information, please contact digitalcommons-group@uri.edu. 


\section{Authors}

Noel P. Gurwick, Daniel M. McCorkle, Peter M. Groffman, Arthur J. Gold, D. Q. Kellogg, and Peter SeitzRundlett 


\title{
Mineralization of ancient carbon in the subsurface of riparian forests
}

\author{
Noel P. Gurwick, ${ }^{1,2}$ Daniel M. McCorkle, ${ }^{3}$ Peter M. Groffman, ${ }^{4}$ Arthur J. Gold, ${ }^{5}$ \\ D. Q. Kellogg, ${ }^{5}$ and Peter Seitz-Rundlett ${ }^{6}$ \\ Received 8 May 2007; revised 11 December 2007; accepted 4 February 2008; published 10 May 2008.
}

[1] Microbial activity in saturated, subsurface sediments in riparian forests may be supported by recent photosynthate or ancient ( $>500 \mathrm{ybp}$ ) soil organic carbon (SOC) in buried horizons. Metabolism of ancient SOC may be particularly important in riparian zones, considered denitrification hot spots, because denitrification in the riparian subsurface is often C-limited, because buried horizons intersect deep flow paths, and because low $\mathrm{C}$ mineralization rates can support ecosystem-relevant rates of denitrification. Buried horizons are common where alluvial processes (stream migration, overbank flow) have dominated riparian evolution. Our objectives were to determine: (1) the extent to which ancient SOC directly supports subsurface microbial activity; (2) whether different $\mathrm{C}$ sources support microbial activity in alluvial versus glaciofluvial riparian zones; and (3) how microbial use of ancient SOC varies with depth. In situ groundwater incubations and ${ }^{14} \mathrm{C}$ dating of dissolved inorganic carbon revealed that ancient SOC mineralization was common, and that it constituted $31-100 \%$ of $\mathrm{C}$ mineralization $2.6 \mathrm{~m}$ deep at one site, at rates sufficient to influence landscape $\mathrm{N}$ budgets. Our data failed to reveal consistent spatial patterns of microbially available ancient $\mathrm{C}$. Although mineralized $\mathrm{C}$ age increased with depth at one alluvial site, we observed ancient $\mathrm{C}$ metabolism $150 \mathrm{~cm}$ deep at a glaciofluvial site, suggesting that subsurface microbial activity in riparian zones does not vary systematically between alluvial and glaciofluvial hydrogeologic settings. These findings underscore the relevance of ancient $\mathrm{C}$ to contemporary ecosystem processes and the challenge of using mappable surface features to identify subsurface ecosystem characteristics or riparian zone N-sink strength.

Citation: Gurwick, N. P., D. M. McCorkle, P. M. Groffman, A. J. Gold, D. Q. Kellogg, and P. Seitz-Rundlett (2008), Mineralization of ancient carbon in the subsurface of riparian forests, J. Geophys. Res., 113, G02021, doi:10.1029/2007JG000482.

\section{Introduction}

[2] Over the past two decades, numerous studies have revealed high variability in nitrogen $(\mathrm{N})$ removal among riparian zones [e.g., Hill, 1996; Lowrance et al., 1997; Kellogg et al., 2005]. While the terrestrial-aquatic interface has generally been considered a hot spot of $\mathrm{N}$ removal in the landscape [Hill, 1996; Lowrance et al., 1997; Kellogg et al., 2005], this high and largely unexplained variability has inhibited widespread adoption and evaluation of riparian zones as a solution to $\mathrm{N}$ pollution problems. In addition, most research on microbial activity and $\mathrm{N}$ removal in riparian zones has focused on surface soils even though

\footnotetext{
${ }^{1}$ Program in Biogeochemistry, Department of Natural Resources, Cornell University, Ithaca, New York, USA.

${ }^{2}$ Now at Department of Global Ecology, Carnegie Institution of Washington, Stanford, California, USA.

${ }^{3}$ Department of Geology and Geophysics, Woods Hole Oceanographic Institution, Woods Hole, Massachusetts, USA.

${ }^{4}$ Institute of Ecosystem Studies, Millbrook, New York, USA.

${ }^{5}$ Department of Natural Resource Science, Kingston Coastal Institute, Kingston, Rhode Island, USA.

${ }^{6}$ Moonstone Farms, Matunuck, Rhode Island, USA.

Copyright 2008 by the American Geophysical Union. 0148-0227/08/2007JG000482
}

large volumes of groundwater flow through conductive subsurface sediments where denitrification is usually carbon (C) limited [Groffman et al., 1992; McCarty and Bremner, 1992; Starr and Gillham, 1993]. Because subsurface denitrification is often $\mathrm{C}$ limited, the nature and distribution of soil and sediment $\mathrm{C}$ can have a major influence on groundwater $\mathrm{N}$ removal.

[3] Soil C characteristics vary among riparian zones in different hydrogeologic settings [Gold et al., 2001]. In the subsurface of riparian zones on glaciofluvial deposits (formed during glacial melt), C-rich microsites derived from plant roots support denitrification [Gold et al., 1998; Jacinthe et al., 2003]. Where alluvial processes (stream migration and overbank flow) have dominated riparian evolution, the subsurface often contains buried soil lenses and horizons that can be thousands of years old (Figure 1). Despite their age, these buried horizons appear to harbor microbially available $\mathrm{C}$ that can support ecosystem-relevant rates of denitrification [Fustec et al., 1989; Gurwick et al., 2008; Hill and Cardaci, 2004].

[4] While the finding that root-derived $\mathrm{C}$ fuels denitrification in glaciofluvial riparian zones is relatively uncontroversial, the proposition that microbial activity relevant to contemporary element budgets depends upon ancient $\mathrm{C}$ in buried horizons differs from widely accepted views of 
(a)

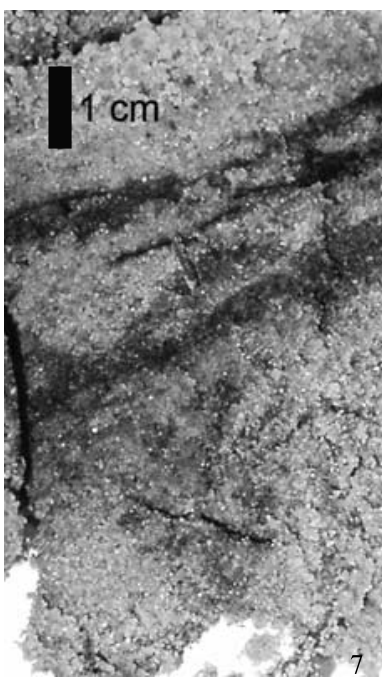

(b)

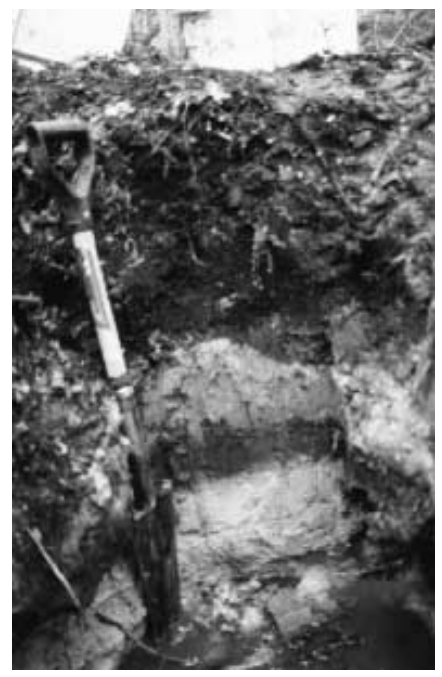

Figure 1. Soil organic carbon in soil profiles at alluvial riparian zones: (a) lenses and (b) a buried horizon. These buried, carbon-rich soils are often thousands of years old yet appear to support microbial activity in the subsurface.

ecosystem $\mathrm{C}$ dynamics. Most $\mathrm{CO}_{2}$ associated with microbial respiration in soil derives from recent photosynthate [Hogberg et al., 2001], and litter usually decomposes within years [Moore et al., 1999]. The remaining material has been considered recalcitrant (i.e., unavailable for use by microbes), either because it is inherently difficult to metabolize or because it has become stabilized by association with minerals [Minderman, 1968; Six et al., 2002; Sollins et al., 1996].

[5] In contrast to most perspectives from ecosystem science, geomicrobiologists have embraced the idea that microbes use a wide variety of $\mathrm{C}$ sources, and empirical research suggests that ancient $C$ fuels microbial activity at ecologically significant rates. Methanogenesis in Siberian lakes depends upon Pleistocene-age C [Zimov et al., 1997], and methane production in groundwater is associated with Wisconsinan-age organic C [Parkin and Simpkins, 1995]. Buckau et al. [2000] found mineralization of Miocene organic carbon at $\sim 100 \mathrm{~m}$ depth in groundwater, and Petsch et al. [2001, 2003] observed microbial communities, including anaerobes, growing on black shale. Similarly, carbon in shale formations in aquifers $10-15 \mathrm{~m}$ beneath the land surface can support substantial denitrification if $\mathrm{NO}_{3}^{-}$is available [McMahon et al., 1999].

[6] Evidence that buried horizons and channel deposits support denitrification in alluvial riparian zones [Gurwick et al., 2008; Hill et al., 2000; Well et al., 2005] raises questions about the role that ancient $\mathrm{C}$ plays in regulating the $\mathrm{N}$ cycle and about riparian zone classifications. First, does old soil organic carbon (SOC) in buried horizons directly support microbial activity, or does it act as a magnet for young $\mathrm{C}$ in the subsurface? Roots proliferate in organic matter-rich areas [Bilbrough and Caldwell, 1995; Eissenstat and Caldwell, 1988], and dissolved organic carbon (DOC) leached from surface soils may adhere to particles of stabilized organic matter in the subsurface [Dunnivant et al., 1992]. Thus, ancient $C$ may facilitate the formation of young-C hot spots in the subsurface without itself being metabolized.

[7] Second, do different C sources fuel subsurface denitrification in different types of riparian zones? In contrast to buried horizons, relatively young $\mathrm{C}$ (years to decades old) may enter the riparian subsurface via deep roots or DOC leached from surface soils. If the supply of microbially available $\mathrm{C}$ in the riparian subsurface varies systematically between alluvial and glaciofluvial (outwash) settings, then mappable landscape features may distinguish among riparian zones that vary in subsurface microbial activity and associated ecosystem processes such as $\mathrm{N}$ sink strength.

[8] In this study, our objectives were to determine: (1) the extent to which ancient $\mathrm{C}$ directly supports microbial activity in buried horizons in the riparian subsurface; (2) whether the mix of $\mathrm{C}$ sources that support microbial activity in the riparian subsurface differs between riparian zones in glaciofluvial and alluvial landscape settings; and (3) how the mix of $\mathrm{C}$ sources fueling microbial activity varies with depth in the subsurface. We expected that mineralization of ancient $\mathrm{C}$ would be more common at alluvial than at glaciofluvial sites, and that respired $\mathrm{C}$ at alluvial sites would become progressively older with depth, corresponding to the increasing age of buried horizons.

\section{Methods and Site Descriptions}

[9] We measured the ${ }^{14} \mathrm{C}$ signature of dissolved inorganic carbon (DIC) in the subsurface of riparian zones in alluvial and glaciofluvial settings and conducted in situ groundwater incubation experiments to estimate the ${ }^{14} \mathrm{C}$ signature of $\mathrm{C}$ actually mineralized at different depths in the riparian subsurface. In addition, we measured the ${ }^{14} \mathrm{C}$ signature of SOC associated with buried soil horizons in the riparian subsurface. The ${ }^{14} \mathrm{C}$ signature of DIC produced at specific locations in the subsurface should reflect the mean age of $\mathrm{C}$ sources being metabolized, enabling us to compare the age of SOC being metabolized with the age of the bulk SOC pool.

\subsection{Site Descriptions and Instrumentation}

[10] We sampled groundwater at four riparian zones in two hydrogeologic settings on low (1st-3rd) order streams in the Pawcatuck River watershed, Rhode Island. Two sites (GF-1 and GF-2) were characterized by glaciofluvial deposits and two (AL-1 and AL-2) by alluvium. Specific site locations were: GF-1 $\left(41^{\circ} 28^{\prime} \mathrm{N}, 71^{\circ} 35^{\prime} \mathrm{W}\right), \mathrm{GF}-2\left(41^{\circ} 28^{\prime} \mathrm{N}\right.$, $\left.71^{\circ} 32^{\prime} \mathrm{W}\right)$, AL- $1\left(41^{\circ} 29^{\prime} \mathrm{N}, 71^{\circ} 41^{\prime} \mathrm{W}\right)$, and AL-2 $\left(41^{\circ} 34^{\prime} \mathrm{N}\right.$, $\left.71^{\circ} 43^{\prime} \mathrm{W}\right)$. All sites had low $(<3 \%)$ surface slopes and vegetation dominated by approximately 80 year old Acer rubrum. All sites were $200-500 \mathrm{~m}$ from roads and were generally remote, but a Christmas tree farm sat roughly $100 \mathrm{~m}$ uphill from GF-1. The alluvial sites were characterized by entisols of moderate $\mathrm{pH}(5.3-6.5)$ while the glaciofluvial sites were more acidic $(\mathrm{pH} 5.0-5.8)$ and dominated by histosols (GF-1) or inceptisols (GF-2). All soils had very low concentrations of carbonate minerals. Groundwater dissolved oxygen at these sites generally ranges from $2-$ $8 \mathrm{mg} \mathrm{L}^{-1}$ at glaciofluvial sites and is usually $<2$ at alluvial sites. Mean dissolved organic carbon (DOC) concentrations 
range from $0.5-4.0 \mathrm{mg} \mathrm{L}^{-1}$ below $150 \mathrm{~cm}$ and $1.5-$ $13.4 \mathrm{mg} \mathrm{L}^{-1}$ at $300 \mathrm{~cm}$ [Kellogg et al., 2005]. Sites GF-1, GF-2, Al-1, and AL-2 correspond to sites described in more detail by Kellogg et al. [2005] as A, B, C, and D.

[11] At each site, we had previously installed 3 minipiezometers at each of 3 target depths: $65 \mathrm{~cm}, 150 \mathrm{~cm}$, and $300 \mathrm{~cm}$ (total 9 minipiezometers per site). Minipiezometers were made of narrow gas-impermeable tubing $(0.8 \mathrm{~cm} \mathrm{o.d.)}$ and had been installed with a slide hammer, greatly minimizing disruption to the surrounding sediments. We sampled from minipiezometers at all sites and depths to characterize ambient ${ }^{14} \mathrm{C}$ in summer 2003 and used a subset of sites and depths for in situ incubations and ambient measurements in Nov-Dec 2002. Sites and minipiezometer installation are described in more detail in Kellogg et al. [2005].

\subsection{Buried Horizon Ages}

[12] We used ${ }^{14} \mathrm{C}$ dating to establish the ages of buried horizons at the two alluvial sites. Using soil pits and an auger, we collected buried C-rich lenses 300-350 cm beneath the surface at AL-1 and a buried O horizon 83$93 \mathrm{~cm}$ beneath the surface at AL-2. For the buried O horizon, we separated all recognizable organic matter fragments from the rest of the soil (humic material). Samples were washed in acid (soil) or acid-base-acid (fragments) and then analyzed for ${ }^{14} \mathrm{C}$ (Beta Analytic, Inc.).

\subsection{In Situ Incubations and Groundwater Sampling}

[13] To measure DIC production and the ${ }^{14} \mathrm{C}$ signature of DIC produced in situ, we modified an in situ incubation technique, previously used at these sites to measure denitrification [Addy et al., 2002; Istok et al., 1997]. Because this method is time and labor intensive, and because ${ }^{14} \mathrm{C}$ analysis is expensive, we chose a subset of sites and wells for these experiments. We selected the two sites (GF-1 and AL-1) where the highest denitrification rates had previously been measured [Kellogg et al., 2005] and conducted incubations in two wells at each of the three depths at those sites. In addition, we conducted incubations in two shallow $(65 \mathrm{~cm})$ wells at GF-2, where we had intensively measured root biomass [Gurwick, 2007] and where several other groundwater denitrification studies have been conducted [Groffman et al., 1992; Nelson et al., 1995; Simmons et al., 1992].

[14] We performed in situ groundwater incubations in Nov-Dec 2002. We collected $20 \mathrm{~L}$ of groundwater from each target minipiezometer at least one day in advance of our experiment. No more than two hours before returning to the field, we transferred this groundwater to a $20 \mathrm{~L}$ carboy fitted with a cap containing three ports. We added $\mathrm{KNO}_{3}$ $\left(32 \mathrm{mg} \mathrm{N} \mathrm{L}^{-1}\right)$ to ensure that microbial activity would not be $\mathrm{NO}_{3}^{-}$limited, and potassium bromide $\left(\mathrm{KBr}, 32 \mathrm{mg} \mathrm{Br}^{-} \mathrm{L}^{-1}\right.$ ) as a conservative tracer to estimate dilution during the incubation. We bubbled helium through one port attached to a tube that reached to the bottom of the carboy and had a bubbling stone on the end. A second port, open to the head space of the carboy was routed through a LiCor 6200 infrared gas analyzer. Bubbling continued until the $\mathrm{CO}_{2}$ concentration of the gas leaving the carboy dropped below 10 ppm and often below 2 ppm (approximately $90 \mathrm{~min}$ ), at which point we capped the ports on the carboy for immediate transport to the field.
[15] To collect ambient groundwater samples before starting incubations, we connected a peristaltic pump to the minipiezometer. To ensure the sampled groundwater had not been in contact with the atmosphere via the minipiezometer, we first pumped at least $500 \mathrm{~mL}$ of groundwater and discarded it. We then pumped a sample into a beaker and measured dissolved oxygen concentration and temperature. Continuing to pump slowly, we collected samples for: bromide concentration and DIC chemistry (HDPE bottle, unfiltered) and $\mathrm{NO}_{3}^{-}$concentration (HDPE bottles, filtered with $0.45 \mathrm{uM}$ filters). With a 23 gauge needle attached to the sampling tube, we collected samples for DIC concentration (125 mL serum bottle, pre-flushed and evacuated); and ${ }^{14} \mathrm{C}$-DIC (1 Liter amber glass bottle, pre-flushed and evacuated). We collected multiple samples of each type and collected samples for $\left[\mathrm{Br}^{-}\right]$and $\left[\mathrm{NO}_{3}^{-}\right]$before and after collecting samples for ${ }^{14} \mathrm{C}$-DIC analysis.

[16] Before introducing the amended, degassed groundwater back into the minipiezometer, we bubbled it with helium for five minutes in the field to eliminate $\mathrm{CO}_{2}$ that might have leaked in during transport. We pumped $500 \mathrm{~mL}$ of groundwater from the carboy into a beaker to measure dissolved oxygen and temperature. To verify initial conditions of the amended groundwater, we collected samples from the carboy to measure $\left[\mathrm{Br}^{-}\right]$and $\left[\mathrm{NO}_{3}^{-}\right]$and DIC chemistry. We reintroduced the amended, degassed groundwater into the well at a maximum rate of $13 \mathrm{~L} \mathrm{~h}^{-1}$, taking care to avoid pumping air into the tube when the carboy was near empty. We then took a final sample from the carboy to characterize initial chemistry and sealed the well. Incubations lasted between 5 and $50 \mathrm{~h}$ depending mainly upon the rate at which tracers had been observed to move out of the recovery zone at each site. We collected samples of incubated groundwater with the same methods used to collect ambient groundwater.

\subsection{Collecting Groundwater Samples for ${ }^{14}$ C-DIC Signatures}

[17] To sample groundwater for ${ }^{14} \mathrm{C}$-DIC in association with our in situ incubations, we fitted 1-L amber glass bottles with suba-seal stoppers, flushed them with ultra-pure helium for $5 \mathrm{~min}$, and evacuated each one for $25 \mathrm{~min}$. Our objective was to create a $\mathrm{CO}_{2}$-free atmosphere with sufficient vacuum to allow us to collect $400-800 \mathrm{~mL}$ of groundwater. To collect samples for ${ }^{14} \mathrm{C}$-DIC analysis, we attached a sampling tube to the minipiezometer, threaded it through the peristaltic pump, and attached a non-coring needle to the end of the tube. We pumped $0.5 \mathrm{~L}$ of water from the well and then inserted the needle through the stopper. To minimize intrusion of air, we secured the bottle underwater in a bucket throughout this operation.

[18] We collected additional ambient groundwater samples from all three depths at all four sites in AugustSeptember, 2003. For site-depth combinations matching those used in 2002, we collected samples from the same minipiezometers. We used the same methods as we did to collect ambient groundwater samples in advance of our incubation experiments, with the following exceptions. Groundwater samples were collected by overfilling $500-\mathrm{mL}$ glass bottles, pouring out $\sim 10 \mathrm{~mL}$, adding $100 \mu \mathrm{L}$ of a saturated solution of $\mathrm{HgCl}_{2}$ to inhibit microbial activity, injecting helium into the $\sim 10 \mathrm{~mL}$ headspace to displace 
atmospheric air, and immediately sealing the bottle with a ground glass stopper. We also collected an additional sample, stored in a full, screw-cap HDPE bottle on ice, that we used to measure $\mathrm{pH}$ and alkalinity within $10 \mathrm{~h}$ of sample collection.

\section{5. ${ }^{14}$ C-AMS Analysis}

[19] DIC was extracted from groundwater samples by acidifying groundwater to $\mathrm{pH}<2$ to convert all DIC to $\mathrm{CO}_{2}$, attaching sample bottles to a vacuum line with an in-line recirculating pump, and bubbling the samples for 30-60 min. Trials with samples of known DIC concentration verified that we trapped $>97 \%$ of the DIC within this time interval. We separated $\mathrm{CO}_{2}$ from $\mathrm{H}_{2} \mathrm{O}$ and noncondensible gases using cryotraps and measured $\mathrm{CO}_{2}$ content by expanding the gas into a known volume and measuring the resulting pressure and temperature. Gas samples were stored in flame-sealed glass tubes until analysis. Radiocarbon analysis was performed at the National Ocean Sciences Accelerator Mass Spectrometry Facility (NOSAMS) [NOSAMS, 2005].

\subsection{Groundwater Chemistry}

[20] For ambient groundwater samples collected in 2003 we measured $\mathrm{pH}$, alkalinity, and concentrations of most cations. We also measured cation concentrations in samples of ambient groundwater from wells used for in situ incubations in 2002. We measured $\mathrm{pH}$ and alkalinity at the water quality laboratory at the University of Rhode Island and cation concentrations at the nutrient analysis laboratory in calculated from the change in $\left[\mathrm{Br}^{-}\right]$, and $1-\mathrm{F}_{\text {inc }}$ is the fraction of groundwater in the post-incubation sample derived from ambient groundwater mixed with the plume.

$$
\Delta \mathrm{DIC}_{\text {prod }}=\frac{[\mathrm{DIC}]_{\mathrm{prod}}}{\mathrm{t}_{\mathrm{inc}}}
$$

$\Delta \mathrm{DIC}_{\text {prod }}$ is the rate of DIC mineralization over the course of the incubation, and $t_{\text {inc }}$ is the duration of the incubation.

[22] $[\mathrm{DIC}]_{\text {initial }}$ is $\mathrm{pH}$ dependent. We eliminated all aqueous $\mathrm{CO}_{2}$ from the groundwater before reintroducing it into the well, but in cases of initial $\mathrm{pH}>$ roughly $6, \mathrm{HCO}_{3}^{-}$ remained in solution. We calculated $[\mathrm{DIC}]_{\text {initial }}$ from measurements of $\mathrm{pH}$ and total DIC of ambient groundwater, and measurements of alkalinity from 2003 ambient groundwater samples.

[23] To estimate $\mathrm{C}$ mineralization rates on a per $\mathrm{kg}$ soil basis, we assumed soil porosity of 0.38 and bulk density of $1.65 \mathrm{~g} \mathrm{~cm}^{-3}$ [Kellogg et al., 2005]. In that case, $1 \mathrm{~L}$ of groundwater occupies $2632 \mathrm{~cm}^{3}$, or $4.3 \mathrm{~kg}$ of soil.

\subsubsection{Contribution of Ancient SOC to Mineralization}

[24] First, we calculated the contribution of ancient SOC to total $\mathrm{C}$ mineralization during the incubation by combining a mass balance for DIC with ${ }^{14} \mathrm{C}$-DIC signatures of ambient and incubated groundwater. Our DIC mass balance relies on our measurements of DIC and bromide concentrations in the ambient groundwater and the incubated plume. In our mass balance (equation (3)) we have made the common approximation of multiplying DIC concentrations by ${ }^{14} \mathrm{C}$ signatures. The ${ }^{14} \mathrm{C}$ signature of DIC produced during the course of the incubation, i.e., ${ }^{14} \mathrm{C}_{\text {prod. }}$ is given by:

$$
{ }^{14} \mathrm{C}_{\text {prod }}=\frac{{ }^{14} \mathrm{C}_{\text {final }} *[\mathrm{DIC}]_{\text {final }}-\left({ }^{14} \mathrm{C}_{\text {initial }} *[\mathrm{DIC}]_{\text {initial }} * \mathrm{~F}_{\text {inc }}\right)-\left({ }^{14} \mathrm{C}_{\text {amb }} *[\mathrm{DIC}]_{\text {amb }} *\left(1-\mathrm{F}_{\text {inc }}\right)\right)}{[\text { DIC }]_{\text {prod }}}
$$

the Department of Crop and Soil Science, Cornell University, using inductively coupled plasma spectrometry. Detection limits for calcium, magnesium, and potassium were $0.2,2$, and $10 \mathrm{ug} \mathrm{L}^{-1}$ respectively. Samples of ambient, amended, and incubated groundwater samples from 2002 were analyzed for $\left[\mathrm{Br}^{-}\right],\left[\mathrm{NO}_{3}^{-}\right]$, and $\left[\mathrm{SO}_{4}^{2-}\right]$ by ion chromatography at the analytical laboratory at the Institute of Ecosystem Studies (detection limit $0.02 \mathrm{mg} \mathrm{L}^{-1}$ for all anions).

\subsection{Data Analysis}

\subsubsection{DIC Production}

[21] We calculated DIC production using the following equations:

$$
[\mathrm{DIC}]_{\text {prod }}=[\mathrm{DIC}]_{\text {final }}-\left([\mathrm{DIC}]_{\text {initial }} * \mathrm{~F}_{\text {inc }}\right)-\left([\mathrm{DIC}]_{\mathrm{amb}} *\left(1-\mathrm{F}_{\text {inc }}\right)\right)
$$

$[\mathrm{DIC}]_{\text {prod }}$ is the amount of DIC produced from mineralization during the incubation, $[\mathrm{DIC}]_{\text {final }}$ is $[\mathrm{DIC}]$ measured in the groundwater at the end of the incubation period, $[\mathrm{DIC}]_{\text {initial }}$ is $[\mathrm{DIC}]$ in the groundwater reintroduced to the minipiezometer, $[\mathrm{DIC}]_{\mathrm{amb}}$ is $[\mathrm{DIC}]$ in the ambient groundwater, $F_{\text {inc }}$ is the fraction of groundwater in the postincubation sample derived from the degassed water
We applied this approach first considering only dilution via advection and second considering both advection and the presence of bicarbonate at the beginning of the incubation. We assumed that any DIC present at the beginning of the incubation $\left(\mathrm{DIC}_{\text {initial }}\right)$ had the same ${ }^{14} \mathrm{C}$ signature as DIC in ambient groundwater $\left(\mathrm{DIC}_{\mathrm{amb}}\right)$.

[25] Our assumptions tend to minimize the contribution of ancient $\mathrm{C}$ to total $\mathrm{C}$ mineralization. We initially assumed no dilution during the incubation and no bicarbonate present at the beginning of the incubation. Many sources of microbially available $\mathrm{C}$, such as $\mathrm{DOC}$ leached from forest floor, are relatively young, and the resulting DIC can be carried along the flow path. Therefore, even at depth DIC in ambient groundwater that mixes into the incubation plume via advection, or that was present in the reinjected groundwater as bicarbonate, tends to dilute the signature of ancient $\mathrm{C}$ mineralized during the incubation. Detecting ancient C mineralization in spite of these assumptions would therefore suggest a relatively strong signal.

[26] Second, we calculated a minimum potential contribution of old $\mathrm{C}$ using only the measured ${ }^{14} \mathrm{C}$-DIC signatures of ambient and incubated groundwater and a range of estimates for the age of carbon being mineralized. We assigned an age of $1 \mathrm{ybp}\left({ }^{14} \mathrm{C}+82 \%\right)$ to the contemporary SOC pool and ages consistent with dates of buried horizons 
Table 1. Cation Concentrations, Alkalinity, and $\mathrm{pH}$ of Ambient Groundwater in August-September $2003^{\mathrm{a}}$

\begin{tabular}{|c|c|c|c|c|c|c|c|c|}
\hline \multirow{2}{*}{$\begin{array}{l}\text { Element or Chemical } \\
\text { Property/Depth }\end{array}$} & \multicolumn{2}{|c|}{ GF-1 } & \multicolumn{2}{|c|}{ GF-2 } & \multicolumn{2}{|c|}{ AL-1 } & \multicolumn{2}{|c|}{ AL-2 } \\
\hline & Mean $(\mathrm{n})$ & Range & Mean (n) & Range & Mean $(\mathrm{n})$ & Range & Mean $(\mathrm{n})$ & Range \\
\hline & & $1.9-4.9$ & & $1.7-3.7$ & & $2.6-4.4$ & & $2.1-2.3$ \\
\hline & & $3.6-6.3$ & & $2.0-2.6$ & & $3.0-5.1$ & & nd \\
\hline & & $4.8-6.5$ & & $1.2-1.5$ & & $2.2-3.6$ & & $2.3-3.9$ \\
\hline $\mathrm{Ca}, \mathrm{mg} \mathrm{L}^{-1}$ & & $1.9-6.5$ & & $1.2-3.7$ & & $2.2-5.1$ & & $2.1-3.9$ \\
\hline $65 \mathrm{~cm}$ & $3.6(5)$ & & $2.5(5)$ & & $3.5(7)$ & & $2.2(3)$ & \\
\hline $150 \mathrm{~cm}$ & $4.5(7)$ & & $2.3(4)$ & & $3.7(6)$ & & $2.3(1)$ & \\
\hline $300 \mathrm{~cm}$ & $5.3(6)$ & & $1.4(5)$ & & $3.0(6)$ & & $3.3(7)$ & \\
\hline site mean & 4.5 (18) & & $2.0(14)$ & & 3.4 (19) & & 2.9 (11) & \\
\hline & & $0.4-1.8$ & & $0.8-1.3$ & & $0.9-1.5$ & & $0.5-0.6$ \\
\hline & & $1.2-2.1$ & & $0.6-0.8$ & & $0.7-1.2$ & & nd \\
\hline & & $1.5-2.5$ & & $0.7-0.7$ & & $0.5-0.8$ & & $0.6-0.9$ \\
\hline $\mathrm{Mg}, \mathrm{mg} \mathrm{L}^{-1}$ & & $0.4-2.5$ & & $0.6-1.3$ & & $0.5-1.5$ & & $0.5-0.9$ \\
\hline $65 \mathrm{~cm}$ & $1.2(5)$ & & $1.0(5)$ & & $1.1(7)$ & & $0.5(3)$ & \\
\hline $150 \mathrm{~cm}$ & $1.6(7)$ & & $0.7(4)$ & & $0.9(6)$ & & 0. Six (1) & \\
\hline $300 \mathrm{~cm}$ & $1.8(6)$ & & $0.7(5)$ & & $0.7(6)$ & & 0.8 (7) & \\
\hline site mean & $1.5(18)$ & & $0.8(14)$ & & 0.9 (19) & & 0.7 (11) & \\
\hline $\begin{array}{l}\text { Alkalinity, } \\
\qquad \mathrm{mg} \mathrm{CaCO}_{3} \mathrm{~L}^{-1}\end{array}$ & & $1.2-5.0$ & & $1-4.5$ & & $9.7-14.4$ & & $3.8-5.4$ \\
\hline $65 \mathrm{~cm}$ & $3.1(3)$ & $5.0-8.0$ & $2.8(2)$ & $0-3.0$ & $11.6(3)$ & $20.6-28.3$ & $4.6(2)$ & $8.6-8.8$ \\
\hline $150 \mathrm{~cm}$ & $5.8(3)$ & $7.2-8.0$ & $1.5(2)$ & $0-0.4$ & $23.4(3)$ & $28.6-34.0$ & $8.7(2)$ & $22.8-24.5$ \\
\hline $300 \mathrm{~cm}$ & $7.6(3)$ & & $0.2(2)$ & & 31.7 (3) & & $23.7(2)$ & \\
\hline & & $5.2-5.7$ & & $5.1-5.5$ & & $5.5-6.0$ & & $5.4-5.7$ \\
\hline & & $5.7-5.8$ & & $5.3-5.6$ & & $6.6-6.8$ & & $5.9-5.9$ \\
\hline $\mathrm{pH}$ & & $5.7-6.0$ & & $5.0-5.0$ & & $6.8-7.0$ & & $6.5-6.6$ \\
\hline $65 \mathrm{~cm}$ & $5.5(3)$ & & $5.2(2)$ & & $5.8(3)$ & & $5.5(2)$ & \\
\hline $150 \mathrm{~cm}$ & $5.8(3)$ & & $5.4(2)$ & & 6.7 (3) & & $5.9(2)$ & \\
\hline $300 \mathrm{~cm}$ & $5.8(3)$ & & $5.0(2)$ & & $6.9(3)$ & & $6.6(2)$ & \\
\hline
\end{tabular}

${ }^{a}$ DIC concentration (umoles $\mathrm{L}^{-1}$ ) in ambient (amb) and incubated (inc) groundwater from 2002 and ambient groundwater from 2003. Values are from multiple wells at each site-depth.

to the ancient pool. We estimated the ${ }^{14} \mathrm{C}$ signature of the atmosphere at $1 \mathrm{ybp}$ by extrapolating the northern hemisphere zone 1 atmospheric ${ }^{14} \mathrm{C}$ data set [Hua and Barbetti, 2004] using the relationship ${ }^{14} \mathrm{C}$ (year) $={ }^{14} \mathrm{C}($ year -1$){ }^{0.9885}$. At site AL-1, $260 \mathrm{~cm}$, we initially assigned the ancient pool an age of $16,663 \mathrm{ybp}\left({ }^{14} \mathrm{C}-825 \%\right)$ and then ran the same calculations assuming ages of 12,000, 8,000, and 4,000 ybp.

[27] Again, our assumptions tend to yield a conservative estimate of the importance of old $\mathrm{C}$ to $\mathrm{C}$ mineralization in the riparian subsurface. Although multiple pools of $\mathrm{C}$ could be contributing to mineralization, using a maximum age for the old end-member yields a minimum contribution for mineralization of old C. For the modern end-member, using $1 \mathrm{ybp}$ minimizes the estimated contribution of old C. Had we chosen SOC formed 20 ybp or 40 ybp for this endmember, it would have had a considerably more enriched ${ }^{14} \mathrm{C}$ signature owing to the spike of ${ }^{14} \mathrm{C}$ put into the atmosphere by atomic weapons testing in the $1950 \mathrm{~s}$, and hence would have required more depleted (old) $\mathrm{C}$ mineralization to balance it.

[28] We calibrated ${ }^{14} \mathrm{C}$-ages with: (1) Calib 5.0.1 and the IntCal04 data set for premodern ${ }^{14} \mathrm{C}$ signatures [Reimer et al., 2004; Stuiver et al., 2005]; and (2) CaliBomb using the Northern Hemisphere Zone 1 data set for samples with modern ${ }^{14} \mathrm{C}$ signatures [Hua and Barbetti, 2004; Reimer and Reimer, 2004]. The calibrated ages allow us to use the ${ }^{14} \mathrm{C}$ signature of DIC in a groundwater sample to infer a minimum age of the oldest source contributing to that sample. This differs from assigning an age to the DIC pool of a sample, a step we feel would not be justified because the DIC in any groundwater sample is almost certainly comprised of a mix of DIC pools of varying ${ }^{14} \mathrm{C}$ signatures.

\section{Results}

\subsection{Buried Horizon Ages}

[29] Buried horizons at the alluvial sites were thousands of years old. Carbon-rich lenses $300-350 \mathrm{~cm}$ beneath the surface at AL-1 yielded a calibrated ${ }^{14} \mathrm{C}$ age of 16,270 $17,050 \mathrm{ybp}$, consistent with glacial retreat from the northeastern U.S. At site AL-2, the carbon associated with the humic material was fixed $10,650 \pm 70 \mathrm{ybp}$, whereas the organic matter fragments from this horizon, including roots, formed $4730 \pm 40 \mathrm{ybp}$.

\subsection{Ambient Groundwater Chemistry}

[30] Neither calcium nor magnesium concentration varied systematically between glaciofluvial and alluvial sites, nor did concentrations of calcium plus magnesium change regularly with depth at site AL-1 (Table 1). Both calcium and magnesium concentrations were lower at AL-1 than at GF-1 (Table 1).

[31] Background concentrations of anions relevant to our experiment were generally low. Bromide concentrations were always $<0.1 \mathrm{mg} \mathrm{L}^{-1}$ except in $260 \mathrm{~cm}$ wells at site AL-1, where they were $<0.35 \mathrm{mg} \mathrm{L}^{-1}$. Nitrate concentrations were near or below detection limits at sites GF-2, AL-1, and AL-2 and ranged from $1.8 \mathrm{mg} \mathrm{L}^{-1}(65 \mathrm{~cm})$ to $3.9 \mathrm{mg} \mathrm{L}^{-1}$ $(300 \mathrm{~cm})$ at GF-1. Sulfate concentrations displayed contrasting patterns at GF-1 and AL-1, declining with depth at 
Table 2. Concentrations of Dissolved Inorganic Carbon (DIC) in Ambient and Incubated Groundwater From 2002 and Ambient Groundwater From 2003

\begin{tabular}{|c|c|c|c|c|}
\hline \multirow[b]{2}{*}{ Sample/Depth } & \multicolumn{4}{|c|}{ Site } \\
\hline & GF-1 & GF-2 & AL-1 & AL-2 \\
\hline \multicolumn{5}{|l|}{2002 Ambient } \\
\hline $65 \mathrm{~cm}$ & $0.93(0.88-0.99)$ & $0.80(0.79-0.82)$ & $1.32(1.16-1.47)$ & nd \\
\hline $150 \mathrm{~cm}$ & $0.80(0.71-0.89)$ & nd & $1.19(0.94-1.45)$ & nd \\
\hline $300 \mathrm{~cm}$ & $0.93(0.90-0.96)$ & nd & $0.86(0.79-0.94)$ & nd \\
\hline \multicolumn{5}{|l|}{2002 Incubated } \\
\hline $65 \mathrm{~cm}$ & $0.32(0.17-0.47)$ & $0.59(0.31-0.88)$ & 1.29 & nd \\
\hline $150 \mathrm{~cm}$ & 0.29 & nd & 0.31 & nd \\
\hline $300 \mathrm{~cm}$ & $0.52(0.41-0.64)$ & nd & $0.62(0.60-0.64)$ & nd \\
\hline \multicolumn{5}{|l|}{2003 Ambient } \\
\hline $65 \mathrm{~cm}$ & 0.97 & 1.03 & 2.35 & 1.46 \\
\hline $150 \mathrm{~cm}$ & 0.68 & 0.76 & 1.46 & 0.99 \\
\hline $300 \mathrm{~cm}$ & 1.24 & 0.93 & 1.14 & 1.03 \\
\hline
\end{tabular}

${ }^{\mathrm{a}}$ Units are in milimoles $\mathrm{kg}^{-1}$. Where we analyzed samples from two wells, we report the range of values in parentheses; in other cases we analyzed groundwater from one well at that site-depth combination. No data for a site-depth combination is designated as nd.

AL-1 (15.4-0.5 mg L $\left.{ }^{-1}\right)$ and, like $\mathrm{NO}_{3}^{-}$, increasing with depth at GF-1 (6.6-9.0 mg L $\left.{ }^{-1}\right)$. At GF-1, we also observed increased concentrations with depth for potassium $\left(0.8-1.7 \mathrm{mg} \mathrm{L}^{-1}\right)$ and sodium $\left(0.8-1.5 \mathrm{mg} \mathrm{L}^{-1}\right)$. Dissolved oxygen concentrations ranged from 2.2 to $6.1 \mathrm{mg} \mathrm{L}^{-1}$ at GF-1 and GF-2 and from 0.7 to $1.0 \mathrm{mg} \mathrm{L}^{-1}$ at AL-1. Other measurements of ambient groundwater chemistry (cation concentrations, specific conductance, and temperature) are summarized in Table S1 (available in auxiliary material). ${ }^{1}$

[32] Alluvial sites had higher DIC concentrations than glaciofluvial sites at shallow and intermediate depths (Table 2). In 2003, DIC concentrations at $65 \mathrm{~cm}$ and $150 \mathrm{~cm}$ ranged from 0.99 to $2.35 \mathrm{mmol} \mathrm{kg}^{-1}$ at AL-1 and AL-2, and from 0.68 to $1.03 \mathrm{mmol} \mathrm{kg}{ }^{-1}$ at GF-1 and GF-2 ( $p<0.06,2$-tailed t-test). In 2002, DIC concentrations in 65 and $150 \mathrm{~cm}$ samples were $0.94-1.47 \mathrm{mmol} \mathrm{kg}^{-1}$ at AL-1 and $0.71-0.99 \mathrm{mmol} \mathrm{kg}^{-1}$ at GF-1 and GF-2 ( $\mathrm{p}<0.05$, 2-tailed t-test). In both years, DIC concentrations in the deepest minipiezometers did not differ between alluvial and glaciofluvial sites ( $\mathrm{p}>0.3,2$-tailed $\mathrm{t}$-test). The inter-site difference disappeared in the deepest minipiezometers because concentrations at alluvial sites decreased with depth whereas concentrations in groundwater at glaciofluvial sites remained relatively constant.

\subsection{Isotope Signatures of Ambient Groundwater DIC}

[33] In 2002, the ${ }^{14} \mathrm{C}$ signature of ambient DIC decreased markedly with depth at $\mathrm{AL}-1$, and ${ }^{14} \mathrm{C}$ signatures from both the $150-\mathrm{cm}$ and $260-\mathrm{cm}$ minipiezometers at this site were less than $0 \%$ (Figure 2a). Radiocarbon signatures of DIC in 2002 ambient groundwater from GF-1 were more enriched than those from AL-1 (Figure 2a). In addition, the modest depletion in ${ }^{14} \mathrm{C}$ signatures with depth at GF-1 contrasts the strong decline observed at AL-1 (Figure 2a). We report ${ }^{13} \mathrm{C}$ and ${ }^{14} \mathrm{C}$ signatures for all groundwater samples in Table S2.

[34] In summer, 2003, we observed three patterns in ambient groundwater ${ }^{14} \mathrm{C}$-DIC. First, as in $2002,{ }^{14} \mathrm{C}$-DIC signatures at AL-1 declined with depth, reaching a premodern signature at $260 \mathrm{~cm}$, but this pattern did not appear for

\footnotetext{
${ }^{1}$ Auxiliary materials are available in the HTML. doi:10.1029/ 2007JG000482.
}

samples from AL-2 (Figure 2b). Second, ${ }^{14} \mathrm{C}$-DIC values from $150 \mathrm{~cm}$ and deeper were always more depleted at alluvial sites (AL-1, AL-2) than at glaciofluvial sites (GF-1, GF-2) (Figure 2b). Third, ${ }^{14} \mathrm{C}$-DIC signatures from the

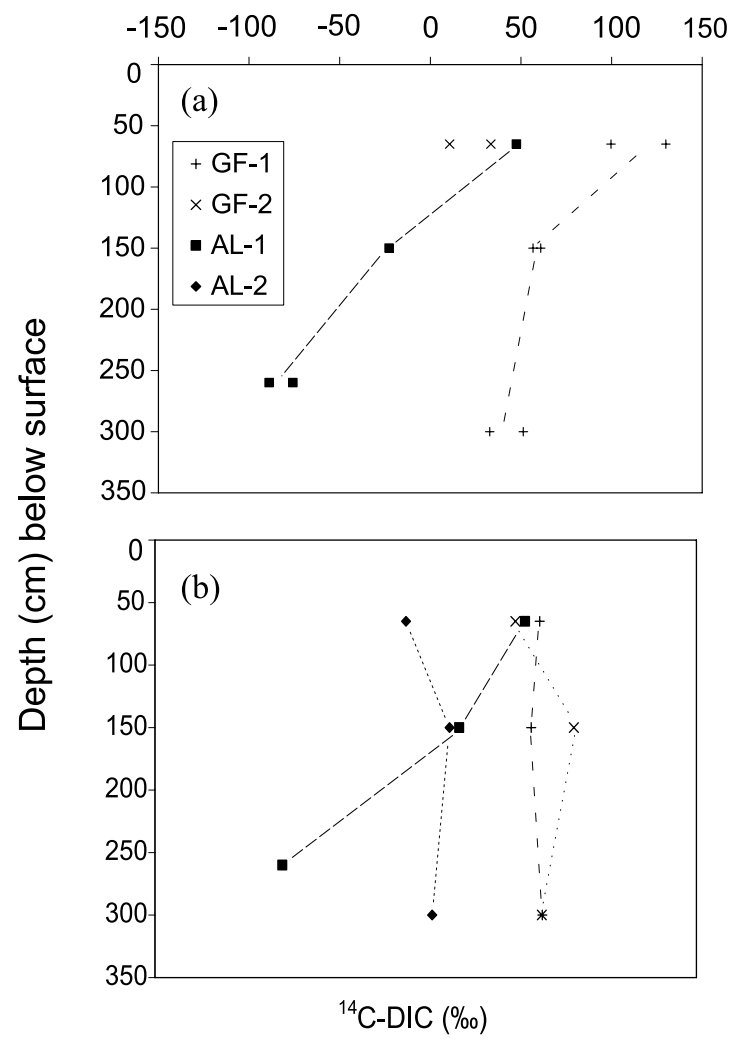

Figure 2. ${ }^{14} \mathrm{C}$ signatures of dissolved inorganic carbon (DIC) in ambient groundwater sampled in (a) 2002 and (b) 2003. Each point indicates chemistry from a single minipiezometer. At alluvial site $\mathrm{AL}-1$, the ${ }^{14} \mathrm{C}$-DIC signatures became increasingly depleted with depth and exhibited clearly pre-modern carbon, suggesting that ancient $\mathrm{C}$ associated with buried channel deposits is microbially available. In 2003, samples from alluvial sites were generally more depleted than samples from outwash sites. 
Table 3. Minimum Ages of Mineralized SOC Required to Account for ${ }^{14} \mathrm{C}$-DIC Signatures of Ambient and Incubated Groundwater Samples From 2002, Ignoring Advection/Dispersion ${ }^{\mathrm{a}}$

\begin{tabular}{|c|c|c|c|c|c|c|}
\hline \multirow[b]{2}{*}{$\underline{\text { Sampling Year }}$} & \multirow[b]{2}{*}{ Site } & \multirow[b]{2}{*}{ Depth, cm } & \multicolumn{2}{|c|}{${ }^{14} \mathrm{C}$-DIC, \%o } & \multicolumn{2}{|c|}{$\begin{array}{l}\text { Minimum Required Age of a Contributing C } \\
\text { Source (ybp) Based on the }{ }^{14} \mathrm{C} \text {-DIC of the: }\end{array}$} \\
\hline & & & Ambient Sample & Incubated Sample & Ambient Sample & Incubated Sample \\
\hline 2002 & GF-1 & 65 & 100 & 44 & $6(4-7)$ & $48(46-49)$ \\
\hline 2002 & GF-1 & 65 & 130 & 31 & $10(8-11)$ & $48(46-49)$ \\
\hline 2002 & GF-1 & 150 & 61 & -33 & $4(4-47)$ & $230(180-380)$ \\
\hline 2002 & GF-1 & 300 & 51 & 155 & $48(46-49)$ & $13(11-14)$ \\
\hline 2002 & GF-1 & 300 & 33 & 45 & $48(46-49)$ & $48(46-49)$ \\
\hline 2002 & AL-1 & 65 & 48 & 69 & $48(46-49)$ & $4(4-5)$ \\
\hline 2002 & AL-1 & 150 & -23 & -56 & $330(50-330)$ & $530(370-580)$ \\
\hline 2002 & AL-1 & 260 & -76 & -167 & $640(580-710)$ & $1390(1320-1460)$ \\
\hline 2002 & AL-1 & 260 & -89 & -194 & $730(610-780)$ & $1660(1560-1760)$ \\
\hline 2002 & GF-2 & 65 & 11 & -63 & $49(47-50)$ & $550(490-610)$ \\
\hline 2002 & GF-2 & 65 & 33 & 24 & $48(46-49)$ & $48(46-49)$ \\
\hline 2003 & GF-1 & 65 & 78 & & $4(4-5)$ & \\
\hline 2003 & GF-1 & 150 & 74 & & $4(4-5)$ & \\
\hline 2003 & GF-1 & 300 & 79 & & $4(4-5)$ & \\
\hline 2003 & GF-2 & 65 & 66 & & $4(4-5)$ & \\
\hline 2003 & GF-2 & 150 & 93 & & $5(4-7)$ & \\
\hline 2003 & GF-2 & 300 & 79 & & $4(4-5)$ & \\
\hline 2003 & AL-1 & 65 & 71 & & $4(4-5)$ & \\
\hline 2003 & AL-1 & 150 & 41 & & $48(46-49)$ & \\
\hline 2003 & AL-1 & 260 & -41 & & $430(320-540)$ & \\
\hline 2003 & AL-2 & 65 & 16 & & $48(46-49)$ & \\
\hline 2003 & AL-2 & 150 & 36 & & $48(46-49)$ & \\
\hline 2003 & AL-2 & 300 & 28 & & $48(46-49)$ & \\
\hline
\end{tabular}

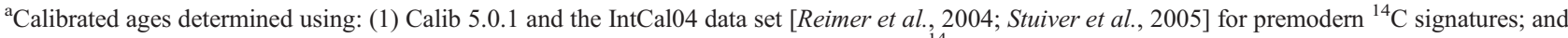
(2) CALIBomb using the Northern Hemisphere Zone 1 data set for samples with modern ${ }^{14} \mathrm{C}$ signatures [Hua and Barbetti, 2004; Reimer and Reimer, 2004]. ${ }^{14} \mathrm{C}$ signatures, values are means of the most likely age range. Where calibration software returned one or more age ranges with $>15 \%$ probability, we report the full range in parentheses.

glaciofluvial sites fell within a narrow range compared to those from the alluvial sites (Figure $2 \mathrm{~b}$ and Table S2). Where site-depth combinations overlap between the two dates, the same minipiezometers were sampled, suggesting that different chemistries reflect temporal rather than spatial variation.

[35] Ambient groundwater DIC from the shallow $(65 \mathrm{~cm})$ minipiezometers always exhibited ${ }^{14} \mathrm{C}$ signatures $>0 \%$, and in all but one case these values were $<+82 \%$, the approximate signature of atmospheric $\mathrm{CO}_{2}$ at the time of collection [Hua and Barbetti, 2004] (Figure 2 and Table 3). The most depleted ${ }^{14} \mathrm{C}$-DIC values in this set were from GF-2 in winter $2002(+11$ and $+33 \%$ ) and AL-2 in summer 2003 $(+16 \%)$

[36] ${ }^{14} \mathrm{C}$-DIC and ${ }^{13} \mathrm{C}$-DIC were inversely correlated at AL-1 $(\mathrm{r}=-0.81, \mathrm{p}<0.05 \mathrm{n}=7)$ and GF-1 $(\mathrm{r}=-0.63, \mathrm{p}<$ $0.07 \mathrm{n}=9$ ) (Figure S1 and Table S2). ${ }^{14} \mathrm{C}$-DIC also correlated negatively with alkalinity at these sites in 2003 $(\mathrm{r}=-0.95, \mathrm{p}<0.005 \mathrm{n}=6)$, but this relationship emerged exclusively from patterns at AL-1 $(r=-0.98, p=0.13)$ and not at all from GF-1 $(r=0.12, p=0.9) .{ }^{14} \mathrm{C}$-DIC signatures bore no relationship to DIC concentrations.

\subsection{In Situ Incubation Experiments}

[37] In most cases, we recovered $>75 \%$ of our tracer confirming that our incubation times were suitable given flow conditions in the aquifer. We observed two patterns in ${ }^{14} \mathrm{C}$-DIC of incubated groundwater. First, these ${ }^{14} \mathrm{C}$ signatures were usually more depleted than ${ }^{14} \mathrm{C}$-DIC of the corresponding ambient groundwater (Table 3). Differences between ambient and incubated samples were often $>50 \%$
(Table 3). In particular, incubated samples from the $260 \mathrm{~cm}$ minipiezometers at AL-1 exhibited ${ }^{14} \mathrm{C}$-DIC signatures of -166 to $-194 \%$ (Figure 3) versus ambient groundwater signatures of -76 to $-89 \%$ (Figure 2). A notable exception to the pattern of more depleted values in incubated samples was the groundwater from a $300 \mathrm{~cm}$ minipiezometer at GF-1, which had a ${ }^{14} \mathrm{C}$ signature of $155 \%$ compared to an ambient value of $51 \%$ (Table 3 ). Second, the pattern of ${ }^{14} \mathrm{C}$ depletion with depth in samples of incubated groundwater at AL-1 (Figure 3) mirrored data from the ambient groundwater (Figure 2).

[38] Carbon mineralization rates at GF-1 and GF-2 exceeded those at AL-1 $(p=0.05,2$-tailed t-test $)$ and showed no strong pattern with depth. Rates of DIC production adjusted for dilution and dispersion of the dosed plume were as high as $0.07 \mathrm{uM} \mathrm{CO}_{2} \mathrm{~kg} \mathrm{soil}^{-1}$ second $^{-1}$. At AL-1, where $\mathrm{pH}$ and alkalinity were high by comparison with our other study sites, accounting for bicarbonate in the initial groundwater yielded negative values for DIC production at one $150 \mathrm{~cm}$ and two $260 \mathrm{~cm}$ wells. Accounting for bicarbonate also yielded an estimate of DIC production $<0$ from one $65 \mathrm{~cm}$ well at GF-1. Below, we consider scenarios with and without accounting for bicarbonate initially present in the reinjected groundwater.

[39] Using a mass balance approach, and assuming no bicarbonate in groundwater at the start of the incubations, we infer that $\mathrm{C}$ mineralized during the incubation must have had a ${ }^{14} \mathrm{C}$ signature ranging from $-515 \%$ o $(260 \mathrm{~cm}, \mathrm{AL}-1)$ to $>200 \%$ ( $65 \mathrm{~cm}, \mathrm{GF}-1$ and AL-1) (Figure 4 and Table 4). The highly enriched value (396\%) required to account for ${ }^{14} \mathrm{C}$-DIC measurements at $\mathrm{AL}-1,65 \mathrm{~cm}$, would require 


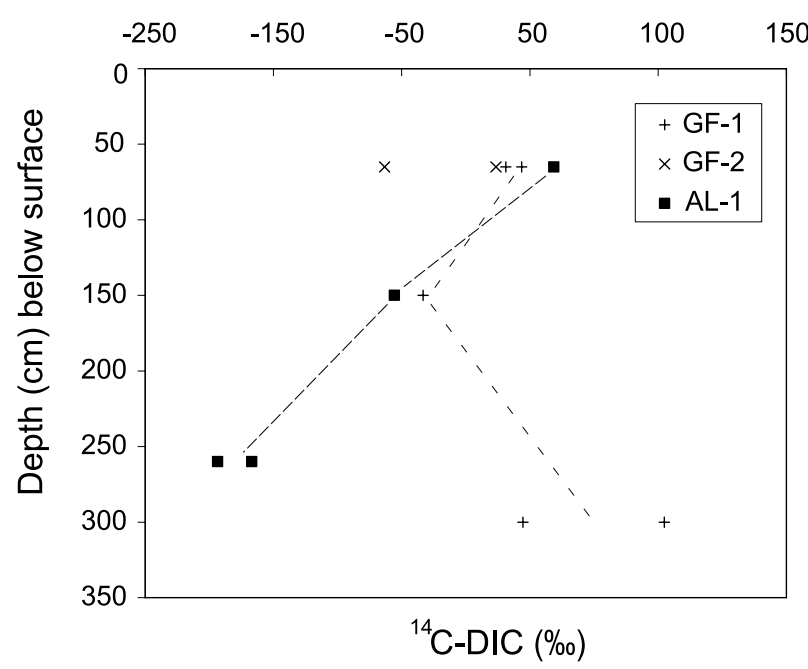

Figure 3. ${ }^{14} \mathrm{C}$-DIC of groundwater collected at the end of our in situ incubation versus depth at alluvial and glaciofluvial sites. Each point indicates chemistry from a single minipiezometer. ${ }^{14} \mathrm{C}$-DIC signatures decline with depth at alluvial site AL-1 and are considerably more depleted than those measured on ambient samples from the same minipiezometers. Compared with ambient groundwater, these samples include more DIC produced locally and immediately (i.e., during the incubations).

carbon inputs from 1963 to 1974 , when bomb ${ }^{14} \mathrm{C}$ in the atmosphere peaked [Hua and Barbetti, 2004]. It is possible that near-surface soil contributing organic $\mathrm{C}$ at $65 \mathrm{~cm}$ formed during this interval, but this ${ }^{14} \mathrm{C}$ estimate may also reflect uncertainty in the DIC budget. Although the most depleted values occurred at AL-1, $260 \mathrm{~cm}$, depleted C was not restricted to alluvial soils and great depth. Carbon mineralized at shallow and intermediate depths at GF-1 had ${ }^{14} \mathrm{C}$ signatures of $<-100 \%$ and $<-285 \%$ respectively (Figure 4 and Table 4). Conversely, ${ }^{14} \mathrm{C}$-enriched carbon was not restricted to glaciofluvial soils and shallow depths; carbon mineralized at $65 \mathrm{~cm}$ at AL-1 and at $300 \mathrm{~cm}$ at GF-1 had mean ${ }^{14} \mathrm{C}$ signatures $>200 \%$ (Figure 4 and Table 4 ).

[40] We repeated our mass balance calculation of the mean radiocarbon signatures of mineralized $\mathrm{C}$, incorporating estimates of bicarbonate present in the groundwater at the beginning of the incubations ( $\mathrm{T}$ zero), and compared these estimates to those derived assuming no bicarbonate. This approach was not possible in cases where estimates of bicarbonate present at $\mathrm{T}$ zero resulted in DIC production estimates $<0$. In most cases, the estimates differed little (Figure 4), reflecting the fact that $>80 \%$ of total DIC in ambient groundwater at GF-1 and GF-2 occurs as $\mathrm{CO}_{2}$, owing to the generally low alkalinity and $\mathrm{pH}$ of these groundwaters (Table 1).

[41] Our analysis of the contribution of ancient $\mathrm{C}$ to total $\mathrm{C}$ mineralization, independent of [DIC] measurements, showed that the ${ }^{14} \mathrm{C}$-depleted end-member contributed a minimum of $31 \%$ of $\mathrm{C}$ mineralization at $260 \mathrm{~cm}$ at AL-1. This value corresponds to the case in which the ancient endmember source has a ${ }^{14} \mathrm{C}$ signature of $-825 \%$, and $100 \%$ of the DIC in the incubated groundwater sample derived from $\mathrm{C}$ mineralization during the incubation (Figure 5).
[42] The contribution of depleted $\mathrm{C}$ increased as the contribution of C mineralization to the DIC pool decreased, and our data suggest substantial DIC contributions from sources other than in situ production. Two additional processes that could have contributed DIC to the incubated sample include advection of ambient groundwater into the plume and bicarbonate in the sample at the start of the incubation. The relatively high $\mathrm{pH}$ and alkalinity of groundwater at AL-1 (Table 1) suggest bicarbonate may have been present in appreciable quantities at the start of the incubation. The measured DIC concentrations were higher in ambient groundwater than in the incubated samples (Table 2), suggesting that dilution by advection could add significant quantities of DIC. The recovery rates at these minipiezometers (39 and 74\%) also indicate that DIC addition occurred via advection or diffusion.

[43] As Figure 5 illustrates, if sources other than in situ production did contribute DIC to the post-incubation sample at AL-1, $260 \mathrm{~cm}$, then ancient $\mathrm{C}$ could have contributed $50-100 \%$ of total $\mathrm{C}$ mineralized during the incubation (shaded area in Figure 5). If $<40 \%$ of the DIC in the incubated sample came from in situ production, then

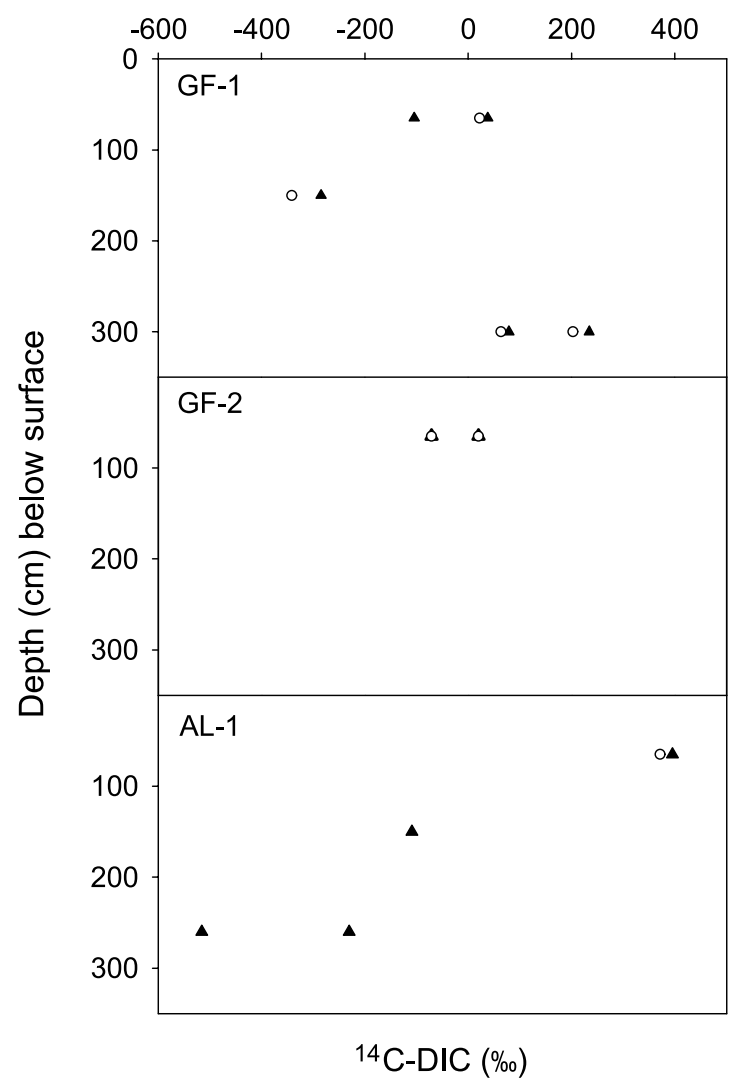

Figure 4. ${ }^{14} \mathrm{C}$ signature of $\mathrm{C}$ mineralized during each incubation. Different symbols show ${ }^{14} \mathrm{C}$ signatures calculated: (1) assuming no DIC in the reinjected groundwater (filled triangles); and (2) using estimated bicarbonate present at time zero, for cases where we calculated DIC production $>0$ (open circles). The highly depleted ${ }^{14} \mathrm{C}$ signatures at GF-1 and AL-1 demonstrate mineralization of ${ }^{14} \mathrm{C}$-depleted SOC at alluvial and glaciofluvial sites. The enriched values at GF-1 $(300 \mathrm{~cm})$ indicate metabolism of decades-old C. 
Table 4. ${ }^{14} \mathrm{C}$ Signatures of DIC Produced During in Situ Incubations, Estimated Based on a Mass and Isotope Balance, and Minimum Ages of Mineralized SOC Required to Account for Those ${ }^{14} \mathrm{C}$-DIC Signatures ${ }^{\mathrm{a}}$

\begin{tabular}{|c|c|c|c|c|c|}
\hline \multirow[b]{2}{*}{ Site } & \multirow[b]{2}{*}{$\begin{array}{l}\text { Depth, } \\
\mathrm{cm}\end{array}$} & \multicolumn{2}{|c|}{$\begin{array}{c}{ }^{14} \mathrm{C} \text {-DIC of C Mineralized During the } \\
\text { Incubation, \%: }\end{array}$} & \multicolumn{2}{|c|}{ Minimum Required Age of a Contributing C Source, ybp } \\
\hline & & $\begin{array}{c}\text { Calculated } \\
\text { Considering } \\
\text { Advection Only }\end{array}$ & $\begin{array}{c}\text { Calculated } \\
\text { Considering } \\
\text { Advection and } \\
\text { Initial Bicarbonate }\end{array}$ & $\begin{array}{c}\text { Based } \\
\text { on }{ }^{14} \mathrm{C} \text { of DIC } \\
\text { Mineralized } \\
\text { During Incubation, } \\
\text { Calculated Using } \\
\text { Advection Only }\end{array}$ & $\begin{array}{c}\text { Based on } \\
{ }^{14} \mathrm{C} \text { of DIC Mineralized } \\
\text { During Incubation, } \\
\text { Calculated Using } \\
\text { Advection and Initial } \\
\text { Bicarbonate }\end{array}$ \\
\hline GF-1 & 65 & 38 & 22 & $47(46-49)$ & $47(46-49)$ \\
\hline GF-1 & 65 & -105 & * & $790(730-860)$ & * \\
\hline GF-1 & 150 & -285 & -342 & $2840(2770-2920)$ & $3600(3490-3700)$ \\
\hline GF-1 & 300 & 234 & 203 & $20(19-21,41-42)$ & $17(16-44)$ \\
\hline GF-1 & 300 & 78 & 63 & $4(4-5)$ & $4(4-5)$ \\
\hline AL-1 & 65 & 396 & 372 & $27(27-28,39-40)$ & $27(27-40)$ \\
\hline AL-1 & 150 & -109 & * & $860(750-970)$ & $*$ \\
\hline AL-1 & 300 & -231 & * & $2080(1970-2200)$ & $*$ \\
\hline AL-1 & 300 & -516 & * & $6620(6500-6730)$ & * \\
\hline GF-2 & 65 & -71 & -71 & $630(560-700)$ & $630(560-700)$ \\
\hline GF-2 & 65 & 20 & 20 & $47(45-48)$ & $47(45-48)$ \\
\hline
\end{tabular}

${ }^{a}$ Calibrated ages determined using: (1) Calib 5.0.1 and the IntCal04 data set for premodern ${ }^{14} \mathrm{C}$ signatures [Reimer et al., 2004; Stuiver et al., 2005]; and (2) CALIBomb using the Northern Hemisphere Zone 1 data set for samples with modern ${ }^{14} \mathrm{C}$ signatures [Hua and Barbetti, 2004; Reimer and Reimer, 2004]. ${ }^{14} \mathrm{C}$ signatures, values are means of the most likely age range. Where calibration software returned one or more age ranges with $>15 \%$ probability, we report the full range in parentheses.

depleted $\mathrm{C}$ accounted for $>50 \%$ of mineralized C. If $20 \%$ of total DIC in the sample resulted from $\mathrm{C}$ mineralization during the incubation, then microbial use of depleted (i.e., ancient) $\mathrm{C}$ accounted for $80-100 \%$ of $\mathrm{C}$ mineralization at this site-depth.

[44] Comparing our estimates of DIC production rates and age of mineralized $\mathrm{C}$, we find that $\mathrm{C}$ mineralization rates were highest at those locations where ${ }^{14} \mathrm{C}$-DIC signatures of mineralized DIC failed to show strong evidence of depleted C, i.e., $0 \% 0<{ }^{14} \mathrm{C}$-DIC $<300 \%$ (Figure 6). This pattern was consistent regardless of whether or not we included in our calculations estimates of bicarbonate present at the start of the incubation.

\section{Discussion}

\subsection{Evidence for Metabolism of Old Carbon}

[45] Our data show that ancient $\mathrm{C}$ associated with buried channel deposits is commonly mineralized in the riparian subsurface in glaciated landscapes. Our mass balance suggests that some of the DIC produced during our incubations at $260 \mathrm{~cm}$ at $\mathrm{AL}-1$ had a ${ }^{14} \mathrm{C}$ signature of $-516 \%$ or lower (Table 4); this requires mineralization of SOC formed at least $6,620 \mathrm{ybp}$. Of the twelve in situ incubations conducted, six demonstrated metabolism of SOC formed $>500 \mathrm{ybp}$ (Figure 7 and Table 4), suggesting that metabolism of ancient $\mathrm{C}$ in the riparian subsurface is common in the types of landscapes we studied.

[46] By demonstrating that ancient $\mathrm{C}$ (rather than recently fixed $\mathrm{C}$ associated with buried horizons) is itself metabolized in saturated subsurface soils, we extend the growing set of investigations that implicate buried horizons as key drivers of denitrification at the terrestrial-aquatic interface [Gurwick et al., 2008; Haycock and Burt, 1993; Hill et al., 2004]. Our findings are also consistent with the observation that microbes use ancient $\mathrm{C}$ in a wide variety of environments including rivers [McCallister et al., 2004], lakes [Zimov et al., 1997], shale formations [Petsch et al., 2001,
2003], aquifers [Buckau et al., 2000; McMahon et al., 1999; Parkin and Simpkins, 1995], and peatlands [Chasar et al., 2000].

[47] Our measurements of ${ }^{14} \mathrm{C}$-DIC in groundwater collected at the end of our in situ incubations and in ambient

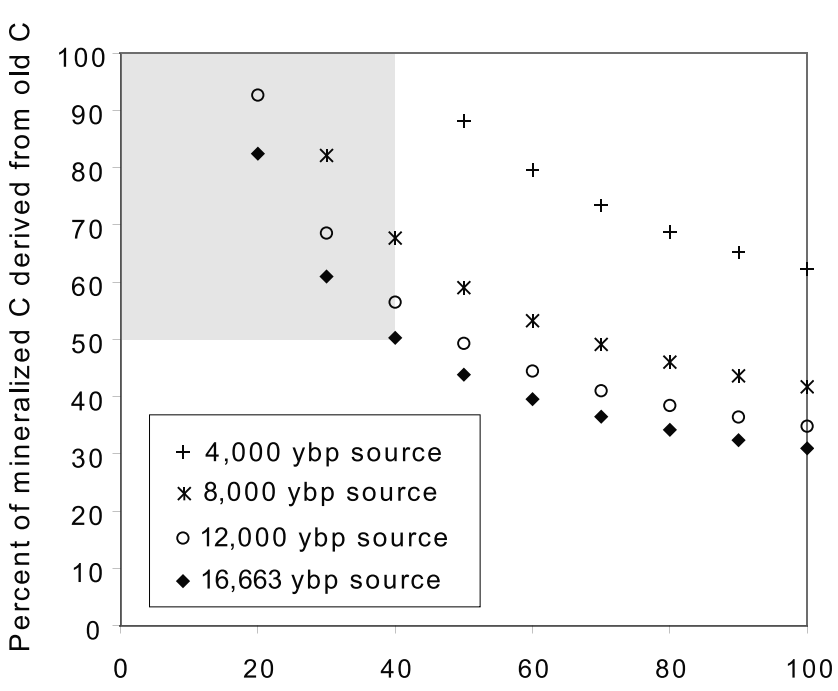

Percent of DIC in incubated sample produced from mineralization during incubation

Figure 5. The relative contribution of ancient $\mathrm{C}$ to C mineralization at alluvial site AL-1 $(260 \mathrm{~cm})$, derived from only the ${ }^{14} \mathrm{C}$-DIC signatures of ambient and incubated groundwater, and realistic estimates of $\mathrm{C}$ source age. The proportion of $\mathrm{C}$ mineralization associated with ancient $\mathrm{C}$ ( $y$ axis) increases as the contribution of $\mathrm{C}$ mineralization (versus advection/dispersion) decreases ( $x$ axis), and as the assumed age of the ancient end-member decreases (different symbols). Ancient SOC accounted for at least 30\% of $\mathrm{C}$ mineralized during our incubation at this site-depth and could have accounted for $50-100 \%$ (shaded area). 


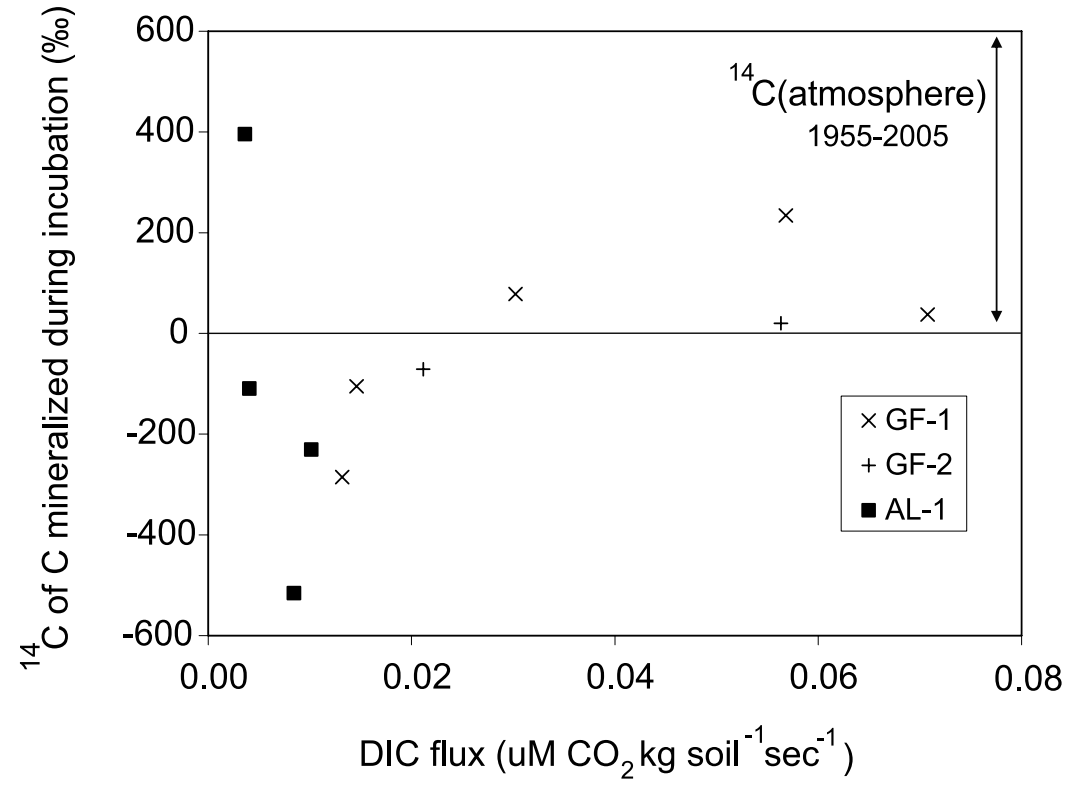

Figure 6. ${ }^{14} \mathrm{C}$ signatures of mineralized $\mathrm{C}$ calculated using estimates of dilution via advection (derived from a $\mathrm{KBr}$ tracer) and assuming no DIC present in reinjected groundwater at the start of the incubations. ${ }^{14} \mathrm{C}$ signatures of $\mathrm{C}$ mineralized during the in situ incubations fall between 0 and $250 \%$ when $\mathrm{C}$ mineralization rates are relatively high and can be either highly depleted or enriched when mineralization rates are relatively slow.

groundwater also point toward metabolism of ancient $\mathrm{C}$. These estimates have less power than our mass balance to detect metabolism of ancient $\mathrm{C}$ but are independent of DIC concentration and groundwater recovery rate, terms that may strongly affect the mass balance calculations. Compared with ambient groundwater, samples collected at the end of our in situ incubations included more DIC produced during the incubations in the immediate vicinity of each minipiezometer, and ${ }^{14} \mathrm{C}$-DIC signatures tended to decline over the course of most our incubations (Table 3). These patterns imply metabolism of SOC at least as old as (and usually older than) the bulk DIC recovered at the end of the incubations. At AL-1, $260 \mathrm{~cm}$, samples collected at the end of our incubations had ${ }^{14} \mathrm{C}$-DIC signatures of $-167 \%$ and $-194 \%$ (Figure 3 and Table 3), compared with $-76 \%$ and $-89 \%$ in ambient samples (Figure 2a and Table 3). Had DIC with these signatures been produced by mineralization of an SOC pool that formed at a single point in time (rather than one composed of SOC of varying ages), that SOC would have formed 1,390-1,660 ybp (Table 3).

[48] Data from ambient groundwater samples alone (Figure 2a and Table 3) also support the hypothesis that microbes mineralize ancient $\mathrm{C}$ in the riparian subsurface. Assuming that all the DIC in ambient groundwater from deep minipiezometers at AL-1 evolved from SOC of uniform age, the SOC mineralized in winter 2002 would have formed 640-730 ybp, and the SOC mineralized in summer 2003 would have formed $430 \mathrm{ybp}$ (Table 3). Because these bulk ${ }^{14} \mathrm{C}$-DIC signatures almost certainly derived from a heterogeneous pool that included recently fixed SOC, the oldest SOC contributing to the mineralized pool must have formed longer ago than that.

[49] The possibility that carbonate mineral dissolution contributes to depleted ${ }^{14} \mathrm{C}$-DIC signatures needs to be considered in the interpretation of these results, but trends in calcium and magnesium concentrations in groundwater support our conclusions about ancient $\mathrm{C}$ mineralization. We observed strong correlations between alkalinity and ${ }^{14} \mathrm{C}$ DIC (at AL-1), and between ${ }^{13} \mathrm{C}$-DIC and ${ }^{14} \mathrm{C}$-DIC (at AL-1 and GF-1, Figure S1). Carbonate minerals tend to be enriched in ${ }^{13} \mathrm{C}$, and because they are generally very old they also have highly depleted ${ }^{14} \mathrm{C}$ signatures. Hence, carbonate dissolution could explain both depleted ${ }^{14} \mathrm{C}$ DIC signatures with depth and the correlation between ${ }^{14} \mathrm{C}$-DIC and alkalinity. However, if carbonate dissolution were driving depleted ${ }^{14} \mathrm{C}$-DIC signatures, we would have expected to see higher concentrations of calcium and magnesium where we found more depleted ${ }^{14} \mathrm{C}$-DIC. This was not the case at our sites; while ${ }^{14} \mathrm{C}$-DIC signatures were low at AL-1 compared to other sites, calcium and magnesium concentrations were highest at GF-1 (Table 1). In addition, ${ }^{14} \mathrm{C}$-DIC signatures at AL-1 declined markedly with depth, but calcium and magnesium concentrations did not increase (Table 1). These data suggest that the declines we observed in ${ }^{14} \mathrm{C}$-DIC signatures with depth at AL-1 did not result solely from dissolution of carbonate minerals.

\subsection{Spatial Patterns of Carbon Sources and Implications for Riparian Classification}

[50] Contrary to expectations, C source did not vary systematically among riparian zones in landscapes mapped as alluvial and glaciofluvial settings [Rector, 1981]. Alluvial sites are characterized by the presence of buried horizons and we therefore expected ancient carbon to be more important at these sites, especially at depth. Although ${ }^{14} \mathrm{C}$-DIC signatures of ambient groundwater collected from alluvial sites in summer 2003 were generally more depleted than values from glaciofluvial sites (Figure 2b), only one of these 


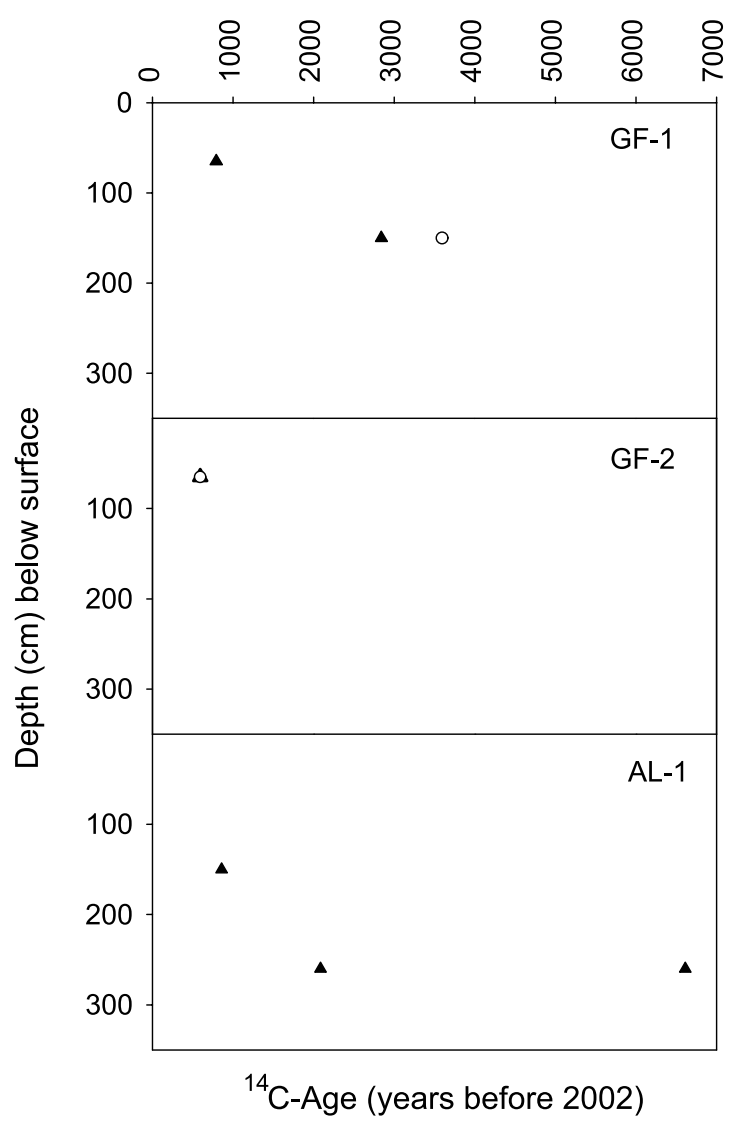

Figure 7. Minimum age of SOC respired during in situ groundwater incubations, by site and depth. Data shown for premodern ${ }^{14} \mathrm{C}$ signatures only. Different symbols show ${ }^{14} \mathrm{C}$ signatures calculated: (1) assuming no DIC in the reinjected groundwater (filled triangles); and (2) using estimated bicarbonate present at time zero, where we calculated DIC production $>0$ (open circles). ${ }^{14} \mathrm{C}$-calibrated ages of $\mathrm{C}$ mineralized during each incubation reveal that $\mathrm{C}$ mineralized during in situ groundwater incubations was often thousands of years old. Because the organic carbon mineralized during the incubations probably did not all form at the same time, some of the mineralized carbon was probably older than these estimates, which assume a pool of uniform age at each minipiezometer.

signatures unequivocally revealed pre-modern $\mathrm{C}$ (Table 3 ). On the other hand, data from our in situ incubations showed that ancient $\mathrm{C}$ plays an important role in glaciofluvial as well as in alluvial riparian zones (Figures 4 and 7 , and Table 4). This result mirrors a previous finding that denitrification failed to differ between riparian zone types, based on studies at these same four sites [Kellogg et al., 2005]. Although the small number of sites constrains our ability to generalize to the landscape, these observations cast doubt on the utility of distinguishing between mapped alluvial and glaciofluvial riparian zones as a basis for predicting subsurface microbial activity and associated $\mathrm{N}$ removal capacity.

[51] We expected respired $\mathrm{C}$ to become progressively older with depth at alluvial sites, reflecting the relative ages of buried horizons, and our data suggest this pattern applies to some alluvial sites but not others. ${ }^{14} \mathrm{C}$-DIC signatures from both ambient and incubated groundwater at AL-1 declined unambiguously with depth (Figures 2 and 3), but ${ }^{14} \mathrm{C}$-DIC signatures from ambient groundwater at AL-2 did not (Figure 2b). Because we measured only ambient ${ }^{14} \mathrm{C}$ DIC at AL-2, it is possible that dilution masked a depleted signature, but groundwater flow rates were comparable between these sites [Kellogg et al., 2005], and the depletion with depth appeared clearly in ambient samples from AL-1. In addition, Kellogg et al. [2005] observed high denitrification rates in situ at AL-1 but not at AL-2, pointing toward contrasting $\mathrm{C}$ dynamics at these alluvial sites.

[52] Apparently, factors beyond those associated with mapped hydrogeologic setting influenced the subsurface C source that microbes used, and our data point to land use in nearby uplands as a variable meriting further study. Carbon mineralized $300 \mathrm{~cm}$ beneath the surface at GF-1, which sits approximately $100 \mathrm{~m}$ downslope from a Christmas tree farm, reflects a "bomb carbon" signal from $~ 1955-$ present, whereas DIC from shallower depth $(150 \mathrm{~cm})$ derived from SOC formed thousands of years ago (Table 4). A possible source of decades-old C $300 \mathrm{~cm}$ deep is organic carbon moving from uplands and into the riparian zone along deep flow paths. Unique among our study sites, concentrations of cations and anions increased with depth at GF-1 (Tables 1 and S1), perhaps reflecting the agricultural history of the adjacent upland. The factors that create these gradients of inorganic compounds may also mobilize and transport organic C. Soil disturbance associated with agriculture has been proposed as a source of old $\mathrm{C}$ metabolized in rivers [Howarth et al., 1991; McCallister et al., 2004]; perhaps the same mechanism operates at smaller scales and via the subsurface in riparian zones.

\subsection{Ancient $C$ and Ecosystem Processes}

[53] Our data strongly support the view that mineralization of ancient SOC can account for a substantial fraction $(30-100 \%)$ of total $\mathrm{C}$ mineralization in the riparian subsurface (Figure 5). These data contrast the finding that ancient $\mathrm{C}$ (up to $8000 \mathrm{ybp}$ ) does not contribute significantly to $\mathrm{CO}_{2}$ production in 3-m deep soil profiles in California [Fierer et $a l ., 2005]$ and the absence of an ancient $C$ signal in fluxes from the Amazon River to the atmosphere [Mayorga et al., 2005]. It is possible that ancient $C$ is being metabolized in those systems also, but that mineralization of recently fixed $\mathrm{C}$ masks the ancient signal in bulk $\mathrm{CO}_{2}$ pools. Our data are in accord with evidence that ancient $\mathrm{C}$ contributes $>25 \%$ of microbial $\mathrm{C}$ assimilation in the Hudson River [McCallister et al., 2004] and is a component of respired $\mathrm{CO}_{2}$ in peatlands [Chasar et al., 2000; Dioumaeva et al., 2002].

[54] Ancient $\mathrm{C}$ may be important in an ecosystem context primarily when young $\mathrm{C}$ sources (which tend to support higher rates of microbial activity) are in short supply and when low $\mathrm{C}$ mineralization rates matter. In the riparian subsurface in this study, a stronger ancient $\mathrm{C}$ signal appeared at locations and times where $\mathrm{C}$ mineralization rates were low (Figure 6). In summer in the Northeastern U.S., we expect relatively high rates of plant-mediated C supply to soils compared to the dormant season. We observed more depleted DIC signatures (Figure 2) and lower DIC concentrations (Table 2) in winter 2002 than in summer 2003. It is conceivable that mineralization of 
ancient $\mathrm{C}$ influences $\mathrm{N}$ removal rates mainly during the winter.

[55] Although absolute rates of $\mathrm{C}$ mineralization associated with ancient $\mathrm{C}$ in the deep subsurface can be low (Figure 6), they are sufficient to have a major influence on $\mathrm{N}$ transport across the terrestrial-aquatic interface and could persist for thousands of years given the $\mathrm{C}$ pool associated with buried horizons [Gurwick et al., 2008]. Riparian zones are considered to be hot spots of landscape-scale $\mathrm{N}$ removal, and microbial activity in these soils is C limited [Groffman et al., 1992; N. Gurwick, unpublished data]. Denitrification rates measured at our study sites $\left(11-230 \mathrm{~g} \mathrm{~N} \mathrm{~m}^{-2}\right.$ based on data in Kellogg et al. [2005]) require C mineralization rates even lower than our measured rates, yet they are sufficient to remove roughly $20 \%$ of the annual $\mathrm{N}$ inputs to the Pawcatuck watershed (estimated as $0.7-4.4 * 10^{6} \mathrm{~kg} \mathrm{~N}$, or $86-1029 \mathrm{~g} \mathrm{~N} \mathrm{~m}^{-2}$ of riparian zone using data in Rosenblatt et al. [2001] and Boyer et al. [2002]).

[56] Acknowledgments. We are grateful to the Cornell Program in Biogeochemistry for graduate research grants and to the U.S. EPA for a STAR Graduate Fellowship to Noel Gurwick. Support for radiocarbon analyses also came from USDANRICGP grant 99-35102-8266, NSF cooperative agreement OCE-9807266, and an Andrew W. Mellon Foundation grant to the Institute of Ecosystem Studies. A graduate research grant to N. Gurwick from the Theresa Heinz Scholars for Environmental Research provided salary for Pete Seitz-Rundlett. We thank the staff at NOSAMS, particularly Ann McNichol and $\mathrm{Al}$ Gagnon, for loaning us equipment and providing advice about stripping $\mathrm{CO}_{2}$ from groundwater. The staff at the URI water quality laboratory granted us access to their laboratory to measure $\mathrm{pH}$ and alkalinity. We thank Gary Blazejewski for collecting samples of buried horizons for radiocarbon dating, and Joe Yavitt, Tim Fahey, Barbara Bedford, and Don Siegel for helpful discussions and advice about sampling design and comments on an earlier draft of this paper.

\section{References}

Addy, K., D. Q. Kellogg, A. J. Gold, P. M. Groffman, G. Ferendo, and C. Sawyer (2002), In situ push-pull method to determine ground water denitrification in riparian zones, J. Environ. Qual., 31, 1017-1024.

Bilbrough, C. J., and M. M. Caldwell (1995), The effects of shading and $\mathrm{N}$-status on root proliferation in nutrient patches by the perennial grass agropyron-desertorum in the field, Oecologia, 103(1), 10-16, doi:10.1007/BF00328419.

Boyer, E. W., C. L. Goodale, N. A. Jaworski, and R. W. Howarth (2002), Anthropogenic nitrogen sources and relationships to riverine nitrogen export in the northeastern USA, Biogeochemistry, 57, 137-169, doi:10.1023/A:1015709302073.

Buckau, G., R. Artinger, S. Geyer, M. Wolf, P. Fritz, and J. I. Kim (2000), Groundwater in-situ generation of aquatic humic and fulvic acids and the mineralization of sedimentary organic carbon, Appl. Geochem., 15(6), 819-832, doi:10.1016/S0883-2927(99)00078-5.

Chasar, L. S., J. P. Chanton, P. H. Glaser, D. I. Siegel, and J. S. Rivers (2000), Radiocarbon and stable carbon isotopic evidence for transport and transformation of dissolved organic carbon, dissolved inorganic carbon, and $\mathrm{CH}_{4}$ in a northern Minnesota peatland, Global Biogeochem. Cycles, 14(4), 1095-1108, doi:10.1029/1999GB001221.

Dioumaeva, I., S. Trumbore, E. A. G. Schuur, M. L. Goulden, M. Litvak, and A. I. Hirsch (2002), Decomposition of peat from upland boreal forest: Temperature dependence and sources of respired carbon, J. Geophys. Res., 107, 8222, doi:10.1029/2001JD000848 [printed 108(D3), 2003].

Dunnivant, F. M., P. M. Jardine, D. L. Taylor, and J. F. McCarthy (1992), Transport of naturally occurring dissolved organic carbon in laboratory columns containing aquifer material, Soil Sci. Soc. Am. J., 56, 437-444

Eissenstat, D. M., and M. M. Caldwell (1988), Seasonal timing of rootgrowth in favorable microsites, Ecology, 69(3), 870-873, doi:10.2307/ 1941037.

Fierer, N., O. A. Chadwick, and S. E. Trumbore (2005), Production of $\mathrm{CO}_{2}$ in soil profiles of a California annual grassland, Ecosystems (N. Y., Print), 8(4), 412-429, doi:10.1007/s10021-003-0151-y.

Fustec, E., E. Chauvet, and G. Gas (1989), Lignin degradation and humus formation in alluvial soils and sediments, Appl. Environ. Microbiol., $55(4), 922-926$.
Gold, A. J., P. A. Jacinthe, P. M. Groffman, W. R. Wright, and R. H. Puffer (1998), Patchiness in groundwater nitrate removal in a riparian forest, J. Environ. Qual., 27(1), 146-155.

Gold, A. J., P. M. Groffman, K. Addy, D. Q. Kellogg, M. Stolt, and A. E. Rosenblatt (2001), Landscape attributes as controls on ground water nitrate removal capacity of riparian zones, J. Am. Water Resour. Assoc., 37(6), 1457-1464, doi:10.1111/j.1752-1688.2001.tb03652.x.

Groffman, P. M., A. J. Gold, and R. C. Simmons (1992), Nitrate dynamics in riparian forests microbial studies, J. Environ. Qual., 21(4), 666-671. Gurwick, N. P. (2007), Carbon in riparian subsurface ecosystems: Sources, lability, and spatial patterns, Ph.D. dissertation, 201 pp., Cornell Univ., Ithaca, N. Y., 15 Jan.

Gurwick, N. P., P. M. Groffman, J. B. Yavitt, A. J. Gold, G. Blazejewski, and M. Stolt (2008), Microbially-available carbon in buried riparian soils in a glaciated landscape, Soil Biol. Biochem., 40(1), 85-96, doi:10.1016/ j.soilbio.2007.07.007.

Haycock, N. E., and T. P. Burt (1993), Role of floodplain sediments in reducing the nitrate concentration of subsurface run-off-A case-study in the Cotswolds, UK, Hydrol. Process., 7(3), 287-295, doi:10.1002/ hyp. 3360070306

Hill, A. R. (1996), Nitrate removal in riparian zones, J. Environ. Qual., 25(4), $743-754$.

Hill, A. R., and M. Cardaci (2004a), Denitrification and organic carbon availability in riparian wetland soils and subsurface sediments, Soil Sci. Soc. Am. J., 68(1), 320-325.

Hill, A. R., K. J. Devito, S. Campagnolo, and K. Sanmugadas (2000), Subsurface denitrification in a forest riparian zone: Interactions between hydrology and supplies of nitrate and organic carbon, Biogeochemistry, 51(2), 193-223, doi:10.1023/A:1006476514038.

Hill, A. R., P. G. F. Vidon, and J. Langat (2004b), Denitrification potential in relation to lithology in five headwater riparian zones, J. Environ. Qual., 33(3), 911-919.

Hogberg, P., A. Nordgren, N. Buchmann, A. F. S. Taylor, A. Ekblad, M. N. Hogberg, G. Nyberg, M. Ottosson-Lofvenius, and D. J. Read (2001), Large-scale forest girdling shows that current photosynthesis drives soil respiration, Nature, 411(6839), 789-791, doi:10.1038/35081058.

Howarth, R. W., J. R. Fruci, and D. Sherman (1991), Inputs of sediment and carbon to an estuarine ecosystem: Influence of land use, Ecol. Appl., l(1), 27-39, doi:10.2307/1941845

Hua, Q., and M. Barbetti (2004), Review of tropospheric bomb ${ }^{14} \mathrm{C}$ data for carbon cycle modeling and age calibration purposes, Radiocarbon, 46, $1273-1298$

Istok, J. D., M. D. Humphrey, M. H. Schroth, M. R. Hyman, and K. T. Oreilly (1997), Single-well, "push-pull" test for in situ determination of microbial activities, Ground Water, 35(4), 619-631, doi:10.1111/j.17456584.1997.tb00127.x.

Jacinthe, P. A., P. M. Groffman, A. J. Gold, and A. Mosier (2003), Patchiness in microbial nitrogen transformations in groundwater in a riparian forest, J. Environ. Qual., 27(1), 156-164.

Kellogg, D. Q., A. J. Gold, P. M. Groffman, K. Addy, M. H. Stolt, and G. Blazejewski (2005), In situ ground water denitrification in stratified, permeable soils underlying riparian wetlands, J. Environ. Qual., 34(2), $524-533$.

Lowrance, R., et al. (1997), Water quality functions of riparian forest buffers in Chesapeake Bay watersheds, Environ. Manage., 21(5), 687-712, doi:10.1007/s002679900060.

Mayorga, E., A. K. Aufdenkampe, C. A. Masiello, A. V. Krusche, J. I. Hedges, P. D. Quay, J. E. Richey, and T. A. Brown (2005), Young organic matter as a source of carbon dioxide outgassing from Amazonian rivers, Nature, 436(7050), 538-541, doi:10.1038/nature03880.

McCallister, S. L., J. E. Bauer, J. E. Cherrier, and H. W. Ducklow (2004), Assessing sources and ages of organic matter supporting river and estuarine bacterial production: A multiple-isotope (Delta C-14, delta C-13, and delta N-15) approach, Limnol. Oceanogr., 49(5), 1687-1702. McCarty, G. W., and J. M. Bremner (1992), Availability of organic-carbon for denitrification of nitrate in subsoils, Biol. Fertil. Soils, 14(3), 219222, doi:10.1007/BF00346064.

McMahon, P. B., J. K. Bohlke, and B. W. Bruce (1999), Denitrification in marine shales in northeastern Colorado, Water Resour. Res., 35(5), 1629-1642, doi:10.1029/1999WR900004

Minderman, G. (1968), Addition, decomposition and accumulation of organic matter in forests, J. Ecol., 56, 355-362, doi:10.2307/2258238.

Moore, T. R., et al. (1999), Litter decomposition rates in Canadian forests, Glob. Change Biol., 5(1), 75-82, doi:10.1046/j.1365-2486.1998.00224.x.

National Ocean Sciences Accelerator Mass Spectrometry Facility (NOSAMS) (2005), General statement of ${ }^{14} \mathrm{C}$ procedures. (Available at http://www.nosams.whoi.edu/images/amsgenst.pdf)

Nelson, W. M., A. J. Gold, and P. M. Groffman (1995), Spatial and temporal variation in groundwater nitrate removal in a riparian forest, J. Environ. Qual., 24(4), 691-699. 
Parkin, T. B., and W. W. Simpkins (1995), Contemporary groundwater methane production from Pleistocene carbon, J. Environ. Qual., 24(2), $367-372$.

Petsch, S. T., T. I. Eglinton, and K. J. Edwards (2001), C-14-dead living biomass: Evidence for microbial assimilation of ancient organic carbon during share weathering, Science, 292(5519), 1127-1131, doi:10.1126/ science. 1058332.

Petsch, S. T., K. J. Edwards, and T. I. Eglinton (2003), Abundance, distribution and delta C-13 analysis of microbial phospholipid-derived fatty acids in a black shale weathering profile, Org. Geochem., 34(6), 731743, doi:10.1016/S0146-6380(03)00040-8.

Rector, D. D. (1981), Soil survey of Rhode Island, U.S. Dep. of Agic. Soil Conserv. Serv., West Warwick, R. I.

Reimer, P. J., and R. Reimer (2004a), CALIBomb radiocarbon calibration. (Available at http://calib.qub.ac.uk/CALIBomb/)

Reimer, P. J., et al. (2004b), IntCal04 terrestrial radiocarbon age calibration, 0-26 cal kyr BP, Radiocarbon, 46, 1029-1058.

Rosenblatt, A. E., A. J. Gold, M. H. Stolt, P. M. Groffman, and D. Q. Kellogg (2001), Identifying riparian sinks for watershed nitrate using soil surveys, J. Environ. Qual., 30(5), 1596-1604.

Simmons, R. C., A. J. Gold, and P. M. Groffman (1992), Nitrate dynamics in riparian forests - Groundwater studies, J. Environ. Qual., 21(4), 659665.

Six, J., R. T. Conant, E. A. Paul, and K. Paustian (2002), Stabilization mechanisms of soil organic matter: Implications for C-saturation of soils, Plant Soil, 241(2), 155-176, doi:10.1023/A:1016125726789.
Sollins, P., P. Homann, and B. A. Caldwell (1996), Stabilization and destabilization of soil organic matter: mechanisms and controls, Geoderma, 74(1-2), 65-105, doi:10.1016/S0016-7061(96)00036-5.

Starr, R. C., and R. W. Gillham (1993), Denitrification and organic-carbon availability in 2 aquifers, Ground Water, 31(6), 934-947, doi:10.1111/ j.1745-6584.1993.tb00867.x.

Stuiver, M., P. J. Reimer, and R. Reimmer (2005), Calib 5.0.1. 2005. (Available at http://www.calib.qub.ac.uk/crev50/)

Well, R., H. Hoper, O. Mehranfar, and K. Meyer (2005), Denitrification in the saturated zone of hydromorphic soils-Laboratory measurement, regulating factors and stochastic modeling, Soil Biol. Biochem., 37(10), 1822-1836, doi:10.1016/j.soilbio.2005.02.014.

Zimov, S. A., Y. V. Voropaev, I. P. Semiletov, S. P. Davidov, S. F. Prosiannikov, F. S. Chapin III, M. C. Chapin, S. Trumbore, and S. Tyler (1997), North Siberian lakes: A methane source fueled by Pleistocene carbon, Science, 277(5327), 800-802, doi:10.1126/science.277.5327.800.

A. J. Gold and D. Q. Kellogg, Department of Natural Resource Science, Kingston Coastal Institute, 1 Greenhouse Road, Kingston, RI 02881, USA.

P. M. Groffman, Institute of Ecosystem Studies, Box AB, Millbrook, NY 12545, USA.

N. P. Gurwick, Department of Global Ecology, Carnegie Institution of Washington, 260 Panama Street, Stanford, CA 94305, USA. (ngurwick@ globalecology.stanford.edu)

D. M. McCorkle, Department of Geology and Geophysics, Woods Hole Oceanographic Institution, Woods Hole, MA 02543, USA.

P. Seitz-Rundlett, Moonstone Farms, Matunuck, RI, USA 